\title{
PROCEEDINGS OF THE UNITED STATES NATIONAL MUSEUM
}

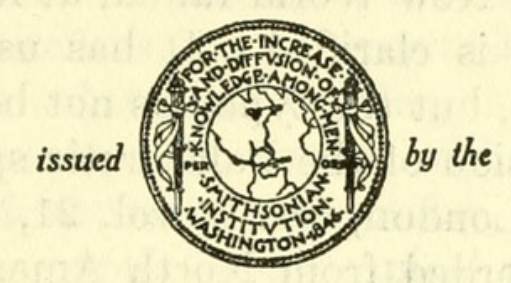

SMITHSONIAN INSTITUTION

U. S. NATIONAL MUSEUM

\section{FLIES OF THE GENUS ODINIA IN THE WESTERN HEMISPHERE (DIPTERA : ODINIIDAE)}

\section{By Curtis W. SABrosky ${ }^{1}$}

The small acalyptrate genus Odinia Robineau-Desvoidy was long referred to the Agromyzidae, but is now generally placed in a separate family, the Odiniidae. Melander (1913, Journ. New York Ent. Soc., vol. 21, p. 248), in revising the North American Agromyzidae, gave a key to four species of Odinia, including one now referred to a different family. Otherwise, the genus has not been reviewed for the Western Hemisphere. The present paper includes nine species, five of them new. After this paper was prepared, I received a teneral female specimen from Beverly Hills, Calif., Aug. 5, 1958, Ben Osuna, that may represent a new species. It was collected in a Steiner fruit-fly trap. It is close to meijerei, but the wing spots are very distinct, those covering the crossveins especially broad and dark, and the midtibia has only a single strong bristle ventrally at the apex.

Six New World species are recorded in the literature: picta (Loew), described from Georgia; williamsi Johnson, described from the Galápagos Islands; immaculata Coquillett, described from New Hampshire; and three species described from Europe and recorded from North America, boletina (Zetterstedt), ornata (Zetterstedt), and maculata

\footnotetext{
${ }^{1}$ Entomology Research Division, Agricultural Research Service, U. S. Department of
} Agriculture, Washington, D. C. 
(Meigen). Of these, immaculata is an agromyzid, a synonym of Phytoliriomyza perpusilla (Meigen). The specimen upon which the lone record of ornata was based (Tucker, 1909, Trans. Kans. Acad. Sci., vol. 22 , p. 303) cannot be located, but the name should probably be eliminated from the New World fauna, at least until the status of true ornata in Europe is clarified. It has usually been considered a synonym of maculata, but the type has not been re-examined in the light of the latest revision of the Palaearctic species by Collin (1952, Proc. Roy. Ent. Soc. London, ser. B, vol. 21, pp. 110-116). Odinia maculata has been recorded from North America several times, but thus far I have not seen maculata, as elucidated by Collin, in North American material. At least three of the species recognized in this paper-conspicua, meijerei, and betulae-have been called maculata in older identifications.

The species of Odinia whose habits are known have been reared in association with wood-boring beetles or from trees attacked by such beetles, or, less commonly, by larvae of cossid or other moths. The larvae of at least one species were found in a Polyporus fungus, although this might also have been in association with the work of coleopterous larvae. In general, it appears probable that the larvae are saprophagous. Adult flies have been taken on Polyporus fungi, rotting stumps, tree trunks, and at bleeding wounds on trees. A new species from Puerto Rico and the Virgin Islands has been caught several times in fruit-fly traps.

Brues, Melander, and Carpenter (1954, Classification of Insects, ed. 2 , p. 377 ) are in error in giving four dorsocentral bristles as a family character. The typical genus Odinia, which contains most of the species in the family, has five dorsocentrals (1 presutural, 4 postsutural). The other genera known to me-Traginops, Schildomyia, Neoalticomerus - have four.

In the present paper the figure numbers correspond to the species numbers, for the convenience of the user. The wings of all nine included species are figured. Specimens examined are in the U. S. National Museum (USNM), Canadian Department of Agriculture (CDA), American Museum of Natural History (AMNH), Museum of Comparative Zoology (MCZ), and the author's collection.

\section{Genus Odinia Robineau-Desvoidy}

Odinia Robineau-Desvoidy, 1830, Essai sur les Myodaires, p. 648. Two species, trinotata and Peleterii, both new. Type-species, $O$. trinotata R.-D.= O. maculata (Meigen), by designation of Rondani, 1875, Bull. Soc. Ent. Ital., vol. 7, p. 2.

The genus Odinia will key to the Agromyzidae in the family key in Curran (1934, Families and Genera of North American Diptera) 
and will key correctly to genus in that family. Figure 4 on page 333 of that work illustrates the typical side view of the head of Odinia, and figure 2 the typical wing venation.

Generic diagnosis: Head bristles long and strong, with three pairs of orbitals, the posterior two reclinate, the anterior mesoclinate and cruciate at tips; both ocellars and postverticals widely divergent, the latter weaker than the other head bristles; inner and outer verticals strong; thoracic bristles equally strong, with 1 humeral, $1+1$ notopleural, 1 presutural, 2 supraalar, 1 postalar, 5 dorsocentral, 1 prescutellar acrostical, 1 subapical and 1 apical pairs of bristles; mesopleuron bare; a short, fine propleural bristle present; 3 sternopleural bristles in a straight line, the anterior long, the others shorter; preapical dorsal bristle present on all tibiae, although short and weak; hind femur of male strongly incrassate; wing venation as figured in present paper, the costa broken at juncture of subcosta and ending at or slightly beyond third vein, anal vein and anal cell present. All species seem to have essentially the same color pattern on the legs (cf. description of biguttata), but the color varies considerably in extent. The two dark bands on the tibiae, one subbasal and the other apical, are quite regular.

Collin (1952) employs the presence or absence of small hairs on the parafrontals between the posterior orbital bristle and the verticals as one of the primary key characters in separating the species. I am inclined to mistrust this character, having seen the hairs present, present on one side only, and absent, in a series reared at the same time and place from the same "host," and certainly appearing to be the same species. However, presence or absence of the hairs may well be characteristic of a majority of individuals of a species, and I have utilized them to a certain extent.

\section{Key to the New World species of Odinia}

1. Wing with a few black spots on or enclosing veins, the wing membrane clear except in one species with two spots in marginal cell (figs. 1-4) . . . . 2

Wing pattern reticulate, or with numerous dark spots most of which are surrounded by a whitish corona (figs. $5-8) \ldots \ldots \ldots \ldots \ldots \ldots \ldots$

2. Marginal cell of wing clear, unspotted; mid tibia ventrally at apex with two strong bristles, subequal in length or unequal............... 3

Marginal cell with two large, evenly spaced black spots between the smaller spots at junctures of first and second veins with costa; mid tibia ventrally at apex with only a single strong bristle....... O. biguttata, new species

3. Mesopleuron gray, at most a streak or trace of brown posterodorsally; wing markings strong, the spots covering the fore and hind crossveins broad and dark, second and third veins with distinct brown clouds about their apices; antenna entirely yellow, at most the apicodorsal margin of third segment faintly browned; large species, typically the body and wing each $5 \mathrm{~mm}$. long . . . conspicua, new species 
Mesopleuron dorsally with distinct broad brown stripe, continued on pteropleuron; spots on wing smaller, and apex of wing clear, the second and third veins not with brown clouds about their apices; antenna with at least a distinct, wedge-shaped black spot anterodorsally on third segment; smaller species, the body and wing each $2.5-4 \mathrm{~mm} . \ldots \ldots \ldots \ldots \ldots .4$

4. Hind crossvein narrowly and indistinctly, or not at all, infuscated, the fore crossvein only weakly so............... O. boletina (Zetterstedt)

Both crossveins broadly and heavily infuscated, that on the hind crossvein

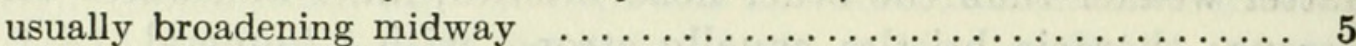

5. Antennal segments 1 and 2 entirely yellow; upper orbit, between posterior orbital and the vertical bristles, usually with a few short black hairs on

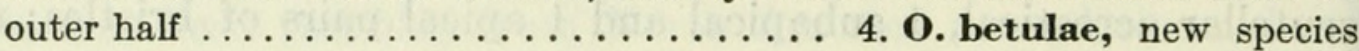

Antennal segments 1 and 2, or at least the first, entirely or chiefly black; upper orbit bare of hairs............... 5. meijerei Collin

6. Wing pattern reticulate (fig. 6); face entirely yellow in ground color; second antennal segment yellow, rounded dorsally ......6. 6. o. picta (Loew)

Wing with numerous black or black-brown spots, most of them surrounded by a whitish corona (figs. 7-9); face broadly black to brown on upper twofifths to half, from eye to eye; second antennal segment narrowly compressed and whitish on dorsal third to two-fifths.............

7. Vibrissa and one or two adjacent oral bristles distinctly flattened, the vibrissa broadly so on basal half ............. 7. . williamsi Johnson

Vibrissa and adjacent bristles slender, not unusually broadly flattened... 8

8. Wing spots large and dark (fig. 8); second and third antennal segments each with large black mark on outer surface, and at least the third equally dark on most of inner surface; front relatively broad, obviously broader than long, and approximately twice the width of an eye; mesonotum without posteriorly bifurcate brown stripe.... 8. O. coronata, new species Spots on wing small and pale (fig. 9); antennal segments almost entirely yellow; front relatively narrow, approximately square, and 1.4-1.5 times the width of an eye; mesonotum with narrow median brown stripe, posteriorly bifurcate, each half ending in a large brown spot beside fourth dorsocentral bristle ............ 9. O. parvipunctata, new species

\section{Odinia biguttata, new species}

Species with two evenly spaced black spots in marginal cell.

Male. Unknown.

Female. Gray-black, heavily pollinose species; frontalia black, contrasting with the bright gray orbits and small frontal triangle, the ocellar tubercle and a spot about the base of each bristle subshining brown; narrow anterior margin of front, lunule, upper face and palpi yellow, the lower half of face and the cheek silvery white on yellow ground color; antenna yellow except for small fuscous spot on outside of second segment and small fuscous spots on inside and outside of third segment; arista yellow at base, the rest black; vibrissa, oral bristles, and postgenal hairs yellow to whitish yellow, all dorsal bristles black, but the anterior pair or two of orbital bristles yellowish distally. Thorax predominantly gray-black, the humeri and disk of scutellum yellowish; bristles and most of hairs set in shining brown spots; mesonotum anteriorly with narrow median 
brown stripe, which forks opposite the third dorsocentral and continues caudad as two broad brown spots; mesopleuron with brown stripe above, and narrow broad margin adjacent to sternopleuron, the latter dark brown above; mesonotal bristles and hairs black, the sternopleural bristles pale distally, and propleural bristle yellowish. Abdomen gray, the numerous hairs and marginal bristles set on small brown spots; second tergum with broad brown band along hind margin, the third to fifth terga each with four brown spots, on the third tergum each submedian spot usually narrowly connected with the adjoining lateral spot. Legs predominantly yellow, more or less mottled with brown: Fore coxa yellowish, browned toward base; femora brown to blackish with some yellow areas, occasionally almost black except at knees, especially on outer surfaces of fore and hind femora; tibiae with subbasal and distal black bands, which vary somewhat in width and in depth of color; tarsi yellow, slightly browned toward apex. Wing hyaline, brown or black-brown spotted (fig. 1), with the usual spots on the veins and crossveins plus two spots in the marginal cell, and spots about the apices of second and third veins. Halteres whitish yellow.

Front relatively narrow, the breadth at vertex slightly greater than the length, 1.27 times the width of an eye and 0.40 times the width of the head, the anterior margin slightly concave, revealing the lunule; frontalia and anterior orbits with a few minute hairs, but none between the posterior orbital and the vertical bristles; vibrissa and oral bristles slender, not broadly flattened.

Middle tibia ventrally with only a single strong bristle, which is over half the length of the mid basitarsus; hind femur with one strong, partly or entirely yellow, preapical anteroventral bristle.

Length of body and of wing, 2.75-3 mm.

Holotype female (USNM 64272), Peter Rest, St. Croix, Virgin Islands, Oct. 13, 1956, R. Delgado. Paratypes, all females (USNM): 3, St. Croix, Virgin Islands, July 18, Sept. 15 (at Christiansted) and Sept. 29, 1956, Delgado; 1, St. Thomas, Virgin Islands, July 28, 1957, Delgado; 1, Isla Verde, Santurce, Puerto Rico, Oct. 9, 1956, A. L. Brown; 2, San Juan, Puerto Rico, May 17 and Aug. 8, 1953, B. B. Sugarman. All specimens were collected in fruit fly traps. I have also seen one female in poor condition, Miami, Fla., Jan. 24, 1957, H. N. McCoy, "in medfly trap."

The upper part of the face in some specimens shows a tinge of brown, and it is possible that normally the face is brown-banded as in the other Neotropical species. All available specimens were mounted out of fluid, and are probably paler than in life.

The wing pattern is the most distinct in the genus, and there should be no difficulty in recognizing the species. The single strong ventral 
bristle on the mid tibia is also unusual in the genus, being found elsewhere only in Odinia hendeli Collin from Europe.

\section{Odinia conspicua, new species}

Large species with broad front, gray mesopleuron, and especially large and conspicuous spots on fore and hind crossveins of the wing.

Male: Chiefly gray-black; head yellowish gray, the lunule, face and cheek silvery gray, yellow in ground color; antenna, palpus, and proboscis orange yellow, the slender portion of arista brown; thorax black in ground color, bright gray pollinose, the humerus, and disk of scutellum except basally, yellowish; pleuron gray, only the sternopleuron slightly browned about bases of sternopleural bristles; abdomen gray with first two terga chiefly brown, four small and indistinct spots on terga three to five, and most hairs and bristles set in small brown spots; legs predominantly yellow, the fundamental pattern as described in biguttata, only weakly indicated; wing as in figure 2, the spots strong and black, those on crossveins especially strong and distinct, and dark clouds about the apices of second and third veins; all hairs and bristles black.

Front very broad, its breadth at vertex 1.2 times the length, 2.13 times the width of an eye, and slightly over half the width of the head, rather uniformly pollinose, the orbits and frontal triangle not clearly delineated, anterior margin strongly emarginate, revealing the large, semicircular lunule; each orbit with a few erect, black hairs on outer half between upper orbital bristle and the verticals; head in profile higher than long by 1.6 times, length at base of antenna 1.8 times that at vibrissa, the front sloping and the long axis of eye diagonal; cheek relatively broad, 0.42 times the height of an eye and 0.29 times the height of the head; vibrissa and oral bristles slender; antenna relatively small. Mid tibia with two strong, subequal apical ventral bristles; hind femur incrassate, 2.12 times as long as broad, with a strong, preapical anteroventral bristle followed by several weaker bristles; hind tibia shorter than hind femur; hind tarsus somewhat broadened distally. Third wing vein rather strongly arched.

Female: As described for male, but the hind femur not strongly incrassate, and anteroventral bristles stronger, with two bristles outstanding on distal third.

Length of body and of wing, $5 \mathrm{~mm}$.

Holotype male (USNM 64273), "Jackson's Island," Md., July 3, 1911, P. R. Myers. Allotype (USNM), Atlanta, Ga., June 3, 1941, P. W. Fattig. Paratypes (all in USNM): male, same data as holotype; 
male, Glen Echo, Md., July 4, 1921, J. R. Malloch (det. Malloch as O. maculata Meigen); male, Plummer's Island, Md., Aug. 3, 1915, at light, R. C. Shannon (det. Shannon as O. picta Loew); female, Springfield, Mass., Dimmock (No. 1841a).

The type locality, an island in the Potomac River a few miles above Washington, D. C, and slightly above Plummer's Island, is now called Turkey Island.

In addition to the above I have also seen two specimens in poor condition, a male from Glen Echo, Md. (same data as paratype), and a female from Springfield, Mass., Dimmock (No. 1843bb).

The two females reared by Dimmock were stated in his notes to be "parasites," and were reared under the following circumstances: No. 1841a, from tenebrionid larva (?Scotobates) under decaying bark of Populus grandidentata, the odiniid emerging from the beetle larva and pupating about May 8, 1901, and the adult fly emerging about June 5, 1901; No. 1843bb, from a number of tenebrionid larvae, apparently all Scotobates calcaratus (Fabricius), in decaying wood of Populus grandidentata, the fly larvae emerging and pupating May 23, 1901, and the flies appearing June 5, 1901.

This species is the largest that I have seen in the genus. It is distinguished from others with the same standard wing pattern by the combination of light colored body and broad, dark wing spots. In the revision of Palaearctic species by Collin (1952), it would appear to key to O. xanthocera Collin on the basis of the yellow antenna, but that species is described as much smaller ( $3 \mathrm{~mm}$.), with a distinct brown stripe on upper mesopleuron, no upper orbital hairs, anteroventral spur on mid tibia only half the length of ventral spur, and the spots on the crossveins small and faint.

\section{Odinia boletina (Zetterstedt)}

Milichia boletina Zetterstedt, 1848, Diptera Scandinaviae . . , vol. 7, p. 2721 (Sweden).

This species is characterized by the pale wing, the hind crossvein being indistinctly or not at all infuscated, and the other spots rather weak and indistinct. The upper part of the pleuron has a broad brown stripe, the upper orbits are bare, and the mid tibia ventrally has one long and one short apical bristles.

I have seen four females (in CDA) which agree with European material, and are recorded as boletina, at least pending further study by comparison of male genitalia: Hemmingford, Quebec, June 21, 1929, J. B. Maltais; Ottawa, Ontario, July 5, 1938, G. E. Shewell; Waterton, Alberta, July 13 and 15, 1923, H. L. Seamans. 


\section{Odinia betulae, new species}

Species with chiefly yellow antenna, broad brown stripe on upper mesopleuron, and distinct spots on the wing veins.

Male: Chiefly gray-black, a narrow anterior margin of front, antenna (except for wedge-shaped spot distad of the arista), base of arista, palpus, humerus indistinctly, scutellum faintly at apex, and legs in part, yellow; face and cheek silvery white on yellow ground color; mesonotum with two faint, irregular brown spots between the fourth dorsocentral bristles, and slight browning in upper angle of notopleuron; pleuron with two brown stripes, one across upper mesopleuron and pteropleuron, the other including upper sternopleuron and lower margin of mesopleuron; abdomen with brown bands on first and second terga, and four rounded spots on each of terga 3 to 5 , the marginal bristles and many of the hairs set in small brown spots; legs variably marked with brown to blackish areas, the fundamental pattern approximately as described for biguttata; wing (fig. 4) with strong, black-brown spots; halter whitish yellow; all hairs and bristles black.

Front proportionately longer than usual, appearing almost square, and measuring barely wider than long, but the width at vertex twice the width of an eye and half the width of the head; orbits and triangle fairly distinct, bright gray pollinose compared with the black-gray of the frontalia; each orbit with a few erect black hairs on outer half, and usually a few between upper orbital bristle and the verticals; cheek comparatively narrow for the genus, at its widest two-fifths the greatest height of the eye and 0.28 times the height of the head; vibrissa and oral bristles slender; antenna relatively small. Acrostical setae in about six rows between the dorsocentral bristles. Mid tibia with two apical ventral bristles, the posterior weaker than the anterior and about two-thirds as long; hind femur greatly incrassate, only 1.8 times as long as broad, the hind tibia slightly shorter; hind tarsus somewhat broadened distally.

Female: As described for male, except as follows: Third antennal segment slightly but distinctly larger than in male; hind femur not greatly incrassate; hind tarsus ordinary, not broadened distally.

Length of body and of wing, 3.75-4.0 mm.

Holotype male (USNM 64274), China, Maine, reared Mar. 31, 1948. Allotype (USNM), Augusta, Maine, reared Apr. 1, 1948. Paratypes: 3 males (USNM), same data as holotype; female (USNM), same data as allotype; male (USNM), Strong, Maine, July 14, 1947; 2 males and 2 females (USNM), Bingham, Maine, July 9, 1947; 1 male and 3 females (USNM), Bingham, Maine, July 15, 1947; female (CDA), Trinity Valley, British Columbia, July 21, 1938, K. Graham; 6 males and 10 females (CDA), Laniel, Quebec, June 10, 1931, June 6, 


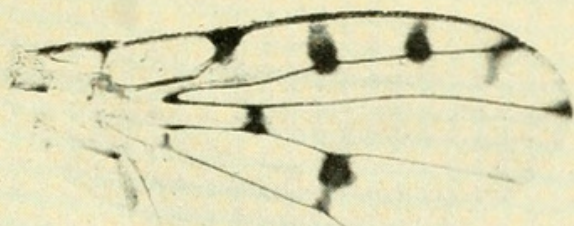

1

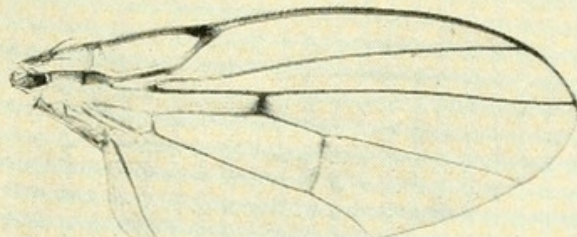

3

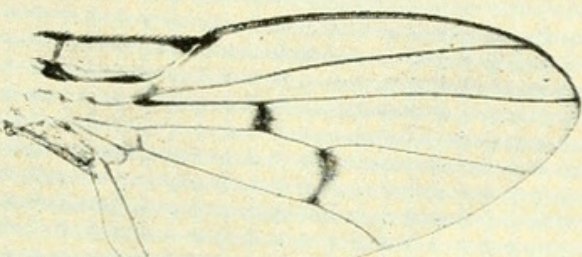

5

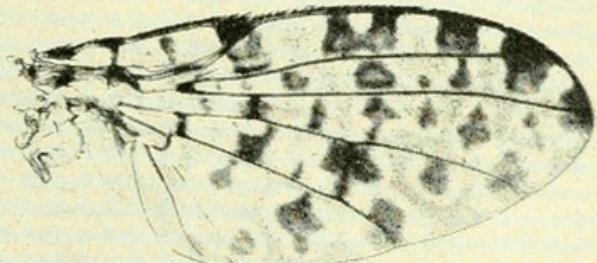

$\mathbf{7}$

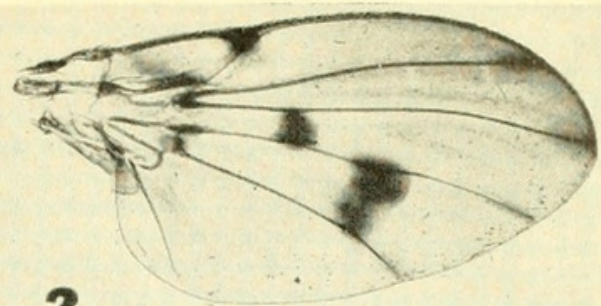

2

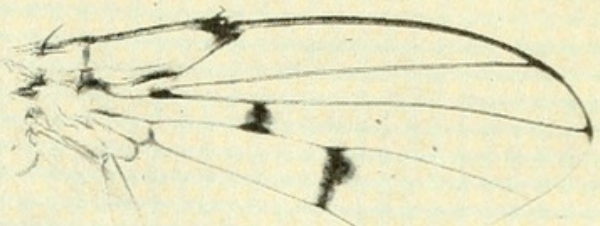

4

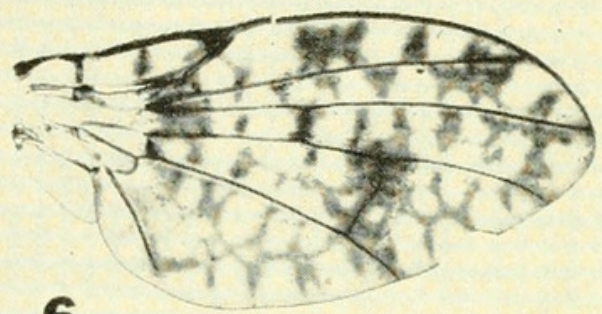

6

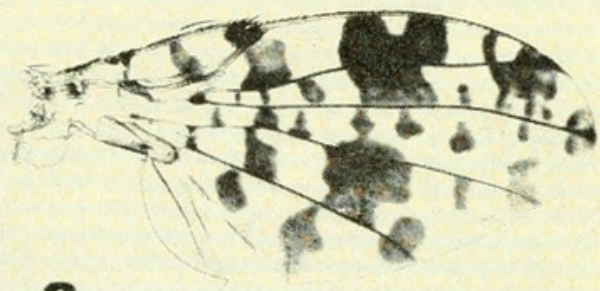

8

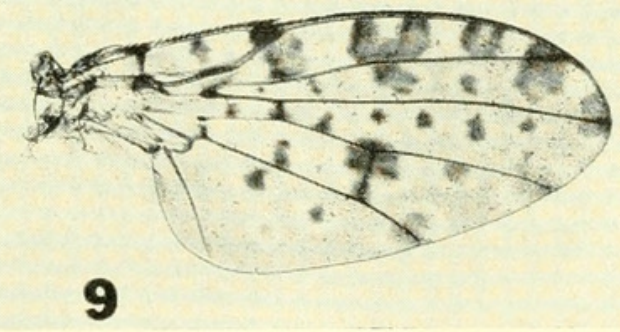

Photographs of wings of species of Odinia: 1, biguttata (paratype, Santurce, Puerto. Rico); 2, conspicua (holotype); 3, boletina (Waterton, Alberta); 4, betulae (male paratype, China, Maine); 5, meijerei (Harrisburg, Pa.); 6, picta (Montgomery Co., Pa.); 7, williamsi (Santa Cruz Island); 8, coronata (female paratype, La Unión, El Salvador), and 9, parvipunctata (male paratype, San Juan, Puerto Rico). 

1933, and various dates from June 7 to July 21, 1934. The paratype from Strong, Maine, is labeled "Ex logs Betula papyrifera"; all other Maine specimens in the type series are labeled "Ex logs Betula papyrifera inf.[ested] by ambrosia beetles+Agrilus anxius." The Quebec specimens emerged in cages placed over felled white and black spruce, balsam, and white birch attacked by various beetles.

This species is close to maculata Meigen as defined by Collin (1952), but the latter is a much darker species, with the first and second antennal segments predominantly brownish or black, the dark area on third antennal segment extending to base of segment on outer surface, the thorax with narrow brown stripe on the midline and in each dorsocentral position, a distinct supraalar stripe, and the scutellum somewhat brownish about the middle. One European female before me, agreeing with Collin's diagnosis, is easily distinguished from the North American species.

Collin $(1952$, p. 116) refers to the association of 0 . ornata (Zetterstedt) with Betula, and believes that it will probably prove to be a distinct species when the type specimen has been studied. However, since the original description states that the basal antennal segments are black, it does not appear that the name ornata need concern us in connection with the Nearctic species found in association with Betula.

\section{Odinia meijerei Collin}

Odinia meijerei Collin, 1952, Proc. Roy. Ent. Soc. London, ser. B, vol. 21, pp. 112, 115 (England, Netherlands).

Limited European material of meijerei is available for comparison, but from this it appears that the species also occurs commonly in North America.

The detailed description given above for biguttata will serve well for meijerei, the chief difference being that the latter has the first two antennal segments, or at least the first, predominantly or entirely black, mesonotum chiefly gray pollinose, upper mesopleuron and pteropleuron with a broad brown stripe, marginal cell clear and unspotted, and membrane not clouded about the apices of second and third veins (fig. 5). The front is broad, slightly over twice the width of an eye and slightly over half the width of the head. The antenna in meijere $i$ is notably larger and darker in the females than in the males. The mid tibia has two apical ventral bristles but the posterior is clearly shorter and weaker than the anterior.

Over 40 specimens are before me, chiefly from several localities in New York and Pennsylvania, reared in connection with studies on forest insects. Other available specimens are from Midland Co., Mich., June 11, 1939, R. R. Dreisbach (USNM); Dauphin Co., Pa., May 3, 1897 (USNM); lower Westchester Co., N. Y., May 22, 1934, 
"reared elm sect.," A. P. Jacot (USNM); Galveston, Tex., Sept. 21, 1956, A. B. Beavers (USNM); Kearney, Arlington Co., Va., Oct. 2, 1912, F. Johanson (USNM); East Lansing, Mich., July 9, 1940, Sabrosky (author's collection); Nyack, N. Y., May 18-20, 1936, "from elm" (AMNH); Maynooth, Ontario, Sept. 5, 1953, and Ottawa, Ontario, May 29, 1955, both J. F. McAlpine (CDA). Four specimens from Westbury, Long Island, N. Y., A. B. Champlain, are probably the basis for the record of Odinia maculata published in "Insects of New York" (1928, p. 865).

The rearing records are not conclusive as to the feeding habits of the odiniid larvae, other than that they are associated with insect damage in trees. Most of the studies on forest insects referred to above recorded the flies as reared during studies of various beetles (Scolytus, Saperda, etc.) reared from dead or dying Hicoria. In one case (Westbury, N. Y.), the dipterous larvae and pupae were found in the primary egg galleries of Scolytus quadrispinosus Say, in Hicoria. Several specimens from Hendersonville, N. C., were reared from maggots found in a tulip tree in which the outer bark was infested with larvae of the phycitid Euzophera ostricolorella Hulst. The Ottawa example was labeled "on bleeding elm stump." Collin (1952) noted that in Europe meijerei "is to be found on diseased elm trees."

\section{Odinia picta (Loew)}

Milichia picta Loew, 1861, Berliner Ent. Zeitschr., vol. 5, p. 358 (Cent. I, no. 99) (Georgia).

This species is adequately characterized in the key. It is unique in the genus in having a reticulated wing pattern. The brown areas are not definite spots surrounded by a whitish corona as in the Neotropical species williamsi, coronata, and parvipunctata. Unlike those species also, the face is yellow and the second antennal segment dorsally is not whitish and compressed.

I have seen only two specimens (MCZ) - the holotype, and a male from Montgomery Co., Pa., June 2, 1895, C. W. Johnson. The Pennsylvania specimen is apparently the one recorded as picta by Johnson (1910, Psyche, vol. 17, p. 235).

\section{Odinia williamsi Johnson}

Odinia williamsi Johnson, 1924, Zoologica, vol. 5, p. 90 (Galápagos Islands).-Curran, 1934, Families and genera of North American Diptera, p. 333, figs. 2,4 .

Species with numerous large dark spots on wing and broadly flattened vibrissae.

Gray-black, the narrow anterior margin of front, lunule, palpi except apices, humeri, and the apex, sides and venter of scutellum 
yellow; whole front rather evenly gray pollinose, the orbits and frontal triangle not sharply distinct; upper half of face broadly seal brown from eye to eye, the lower half silvery white on yellow ground color; second antennal segment black, the dorsal two-fifths compressed and whitish, third antennal segment with broad black stripe on both inner and outer surfaces; arista black, yellow basally; mesonotum with irregular brown spots about bases of bristles, and smaller spots about bases of hairs, but no median brown stripe, the spots especially large about bases of second to fourth pairs of dorsocentrals; mesonotum anterolaterally on each side with a weak brown stripe mesad of humerus and extending caudad to notopleuron through base of presutural bristle; mesopleuron gray above, or with faint trace of brown near posterodorsal angle, but not with brown stripe; lower rim of mesopleuron and upper margin of sternopleuron dark brown; second abdominal tergum without a brown band, and the four brown spots on each of terga 3 to 5 small, rounded, and well separated from each other; legs about as described for biguttata; wing as in figure 7 , with numerous black or black-brown spots scattered over the wing, most of them outlined by a white corona caused, at least in part, by fewer and paler microtrichiae in the surrounding membrane; halteres whitish yellow. All bristles and hairs black.

Front at vertex broader than long, twice the width of an eye and half the width of head, with a few fine hairs on the frontalia and lower orbits but none between the posterior orbital and vertical bristles; vibrissa short, strongly curved, broadly flattened on basal half, the adjacent orbital bristle or two likewise broadened basally. Mid tibia with two strong, subequal apical ventral bristles; hind femur with one strong, preapical, anteroventral bristle. Length of body and of wing, $3-3.5 \mathrm{~mm}$.

I have seen the following material: 4 females (USNM), Isla Santa Cruz, Galápagos, 1948, K. Vinton; male (AMNH), Wollebaek Galápagos-Expedition, 1925; male and female (AMNH), Barrington Island, Galápagos, Oct. 20, 1925, F. X. Williams.

The specimens agree with the original description in all details except in having five pairs of dorsocentral bristles, the normal number for the genus, whereas the description said four pairs. This was undoubtedly an error.

The figures of williamsi by Curran are approximately correct, but the figure of the head fails to show the broad flattening of the vibrissa and one or two oral bristles, and also lacks strong divergent postverticals. In the specimens before me, the wing shows whitish areas around the dark spots over the whole wing, and not merely along the posterior margin, as shown in the figure. 
The flattened vibrissae of this species are apparently unique in the genus.

\section{Odinia coronata, new species}

Species with numerous large dark spots in wing, and slender vibrissae.

Male: Color as described for $O$. williamsi except as follows: Lower portion of second antennal segment with black stripe on outer surface, but inner surface reddish; mesonotum with brown spots about bases of bristles and hairs, and a large, irregular brown spot encompassing and mesad to the base of each fourth dorsocentral bristle, but no median brown stripe; in darkest specimens a brown stripe on each side of mesonotum mesad of humerus and extending caudad through bases of presutural and supraalar bristles to the postalar bristle; mesopleuron predominantly gray, dorsally with a narrow brown stripe, sometimes only a trace of brown; wing pattern (fig. 8) similar to that of williamsi but darker, the median spot in marginal cell and that encompassing the hind crossvein conspicuously larger and darker.

Front slightly narrower than in williamsi, 1.77 times the width of an eye and 0.47 times the width of head, with a few minute hairs as in williamsi; vibrissa long and slender, the adjacent oral bristles slender and almost hairlike. Mid tibial apical bristles as in williamsi; hind femur incrassate as usual in males, but not unusually so, the length 2.07 times the greatest diameter; hind tibia as long as hind femur; the latter with one strong preapical anteroventral bristle.

Female: As described for male, except for the following: Front broader, 1.3 times its own length, twice the width of an eye and onehalf the width of the head; hind femur not enlarged.

Length of body and of wing, $3.5 \mathrm{~mm}$.

Holotype male (USNM 64275) and allotype, La Union, El Salvador, Jan. 25, 1957, P. A. Berry (no. 807). Paratypes (in USNM): 2 females, same data as holotype; male, La Campana, Panama, January-March 1938, James Zetek; male, Palm Beach, Panama, Sept. 17, 1952, light trap, F. S. Blanton; female, Harlingen, Tex., Aug. 8, 1931, R. L. Clayton; female, Allen, Tex., Aug. 14, 1931, F. O. Swan. I have also seen two males in poor condition, not included in the type series, one with same data as the holotype and one with same data as the paratype from Allen, Tex.

This species is a near relative of $O$. williamsi from the Galápagos Islands. The form of the vibrissae is the only difference of consequence. 


\section{$2 \mathrm{BHL}$ Biodiversity Heritage Library}

Sabrosky, Curtis W. 1959. "Flies of the Genus Odinia in the Western Hemisphere (Diptera: Odiniidae)." Proceedings of the United States National Museum 109(3414), 223-236.

https://doi.org/10.5479/si.00963801.109-3414.223.

View This Item Online: https://www.biodiversitylibrary.org/item/32759

DOI: https://doi.org/10.5479/si.00963801.109-3414.223

Permalink: https://www.biodiversitylibrary.org/partpdf/17097

\section{Holding Institution}

Smithsonian Libraries

\section{Sponsored by}

Smithsonian

\section{Copyright \& Reuse}

Copyright Status: NOT_IN_COPYRIGHT

Rights: https://www.biodiversitylibrary.org/permissions/

This document was created from content at the Biodiversity Heritage Library, the world's largest open access digital library for biodiversity literature and archives. Visit BHL at https://www.biodiversitylibrary.org. 